\title{
ERRATUM
}

\section{THE TCL1 FAMILY OF ONCOPROTEINS: CO-ACTIVATORS OF TRANSFORMATION}

Michael A. Teitell

Nature Rev. Cancer 5, 640-648 (2005)

On page 648 of this article, reference 14 was not cited and reference 13 was incorrectly highlighted. The correct references are given below.

13. Gritti, C. et al. Transgenic mice for MTCP1 develop T-cell prolymphocytic leukemia. Blood 92, 368-373 (1998).

14. Bichi, R. et al. Human chronic lymphocytic leukemia modeled in mouse by targeted TCL1 expression. Proc. Natl Acad. Sci. USA 99, 6955-6960 (2002).

This paper provides a genetic model for human B-CLL by dysregulated TCL1 expression in B-cells. 